\title{
Reactivity and Pozzolanic Properties of Biomass Ashes Generated by Wheat and Soybean Straw Combustion
}

\author{
Slobodan Šupić *, Mirjana Malešev (D), Vlastimir Radonjanin, Vesna Bulatović and Tiana Milović \\ Department of Civil Engineering and Geodesy, Faculty of Technical Sciences, University of Novi Sad, \\ 21000 Novi Sad, Serbia; miram@uns.ac.rs (M.M.); radonv@uns.ac.rs (V.R.); vesnam@uns.ac.rs (V.B.); \\ tiana.milovic@uns.ac.rs (T.M.) \\ * Correspondence: ssupic@uns.ac.rs; Tel.: +381-64-0914-861
}

Citation: Šupić, S.; Malešev, M.; Radonjanin, V.; Bulatović, V.; Milović, T. Reactivity and Pozzolanic Properties of Biomass Ashes Generated by Wheat and Soybean Straw Combustion. Materials 2021, 14, 1004. https://doi.org/10.3390/ ma14041004

Academic Editor: Frank Collins

Received: 11 January 2021

Accepted: 5 February 2021

Published: 20 February 2021

Publisher's Note: MDPI stays neutral with regard to jurisdictional claims in published maps and institutional affiliations.

Copyright: (C) 2021 by the authors. Licensee MDPI, Basel, Switzerland. This article is an open access article distributed under the terms and conditions of the Creative Commons Attribution (CC BY) license (https:/ / creativecommons.org/licenses/by/ $4.0 /)$.

\begin{abstract}
A sustainable use of locally available wastes from agriculture as supplementary cementitious materials (SCMs) is an alternative solution for the prevention of excessive raw material usage, reduction of $\mathrm{CO}_{2}$ emission and cost-effective concrete production. This paper studies the reactivity of non-traditional waste SCMs: Wheat straw ash (WSA), mixture of wheat and soybean straw ash (WSSA) and soybean straw ash (SSA), which are abundant as agricultural by-products in Serbia. The chemical evaluation using XRF technique, thermal analysis (TGA/DSC), XRD and FTIR methods were performed along with physical properties tests to investigate the feasibility of utilizing biomass ashes as cement substitutes. The obtained results demonstrate a high pozzolanic activity of WSA, which is attributed to a high reactive silica content of the ash and its satisfactory level of fineness. A wider hump in XRD pattern of WSA compared to WSSA and SSA confirmed that it abounds in amorphous (reactive) phase. The insufficient activity index of soybean-based biomass ashes, characterized with a low silica content, was improved by additional grinding and/or blending with amorphous silica-rich material. This points out the mechanical activation, i.e., grinding procedure, and chemical activation, i.e., modification of the chemical composition, as techniques efficient at producing pozzolanic materials from biomass wastes. Tested biomass ashes are characterized with negligible leaching values of heavy metals, thereby satisfying eco-friendly principles of SCM utilization. The application of biomass ashes as SCMs leads to substantial cost savings, as well as benefits to the environment, such as lower consumption of cement, reduction of $\mathrm{CO}_{2}$ emissions during the production of cement and sustainable waste management.
\end{abstract}

Keywords: activity index; biomass ash; cement; pozzolanic reaction; soybean; thermal analysis; wheat

\section{Introduction}

There is an urgent need to preserve natural resources and reduce $\mathrm{CO}_{2}$ emissions while upholding the principles of sustainable development and keeping up with the uprising concrete production. This need has prompted many researchers from around the world to explore viable options regarding these issues. A variety of experimental studies was carried out on the fresh and hardened properties and durability of pastes/mortar/concrete containing solid wastes, generated by industrial, mining, urban and agricultural activities, as a partial or full cement or aggregate replacement. Correspondingly, the construction industry has been steadily regulated to use SCMs as reflected in several standards worldwide.

The production of cement accounts for approximately $7 \%$ of the global carbon dioxide emissions, as the fabrication of one ton of ordinary Portland cement releases approximately one ton of this greenhouse gas [1]. The use of locally-available materials-industrial and agricultural waste-as engineering products, is one of the promising solutions to the economic and environmental problems of developing countries. These materials can have acceptable levels of pozzolanic activity when chemical composition, combustion conditions and level of fineness are adjusted. High silica content in the form of non-crystalline or 
amorphous silica and a very large surface area of material particle are the key parameters determining the possibility of application of these materials as supplementary cementitious materials (SCMs). They do not exhibit any hydraulic properties of their own; this occurs only in the presence of calcium oxide $(\mathrm{CaO})$ or calcium hydroxide $\left(\mathrm{Ca}(\mathrm{OH})_{2}\right)$, which are generated from the hydration process of cement. Silica and alumina in pozzolana react with these products and form more calcium silicate hydrate (C-S-H) gel, thus reducing the amount of $\left(\mathrm{Ca}(\mathrm{OH})_{2}\right)$. Subsequently, concrete and mortar are stronger, denser and more durable. Since certain SCMs, like silica fume, blast furnace slag and fly ash, have already been commercialized and used in cement industry to partially replace cement, the utilization of other materials is still under investigation.

Various industry by-products, such as silica fume, blast furnace slag and fly ash are being successfully used as SCMs, thereby solving the problem of their improper disposal, conserving natural resources and reducing the amount of $\mathrm{CO}_{2}$ released during the production of cement clinker. Over the last few decades, a growing interest in the development of SCMs derived from industrial and agricultural wastes has been noticed in the scientific literature. The main basis for the valorization of biomass ashes lies in the fact that they contain high amounts of amorphous silica, which makes them suitable as cement substitutes in cement-based composites. Silica content of different types of biomass ashes, used as cement or small aggregate substitutes worldwide, is given in Table 1.

Table 1. Silica content of various biomass ashes.

\begin{tabular}{ccc}
\hline & Silica Content (\%) & Reference \\
\hline Rice husk ash (RHA) & 88.0 & Ki-Bong et al. [2] \\
\hline Corn cob ash (CCA) & 61.8 & Shazim et al. [3] \\
\hline Wheat straw ash (WSA) & 65.7 & Qudoos et al. [4] \\
\hline Palm oil fuel ash (POFA) & 63.6 & Chindaprasirt et al. [5] \\
\hline Sugar cane straw ash (SCSA) & 36.5 & Moraes J.C.B. et al. [6] \\
\hline Sunflower stalk ash (SSA) & 26.0 & Aksog an O. et al. [7] \\
\hline Bamboo leaf ash (BLA) & 80.4 & Cociñaa E.V. et al. [8] \\
\hline Groundnut shell ash (GSA) & 41.4 & Alaneme K.K. et al. [9] \\
\hline Saw dust ash (SDA) & 69.3 & Raheem A.A. et al. [10] \\
\hline Oyster shell ash (OSA) & 4.6 & Gengying Li et al. [11] \\
\hline Mischantus ash (MA) & 57.0 & Wigley F. et al. [12] \\
\hline Barley ash (BA) & 31.0 & Risnes H. et al. [13] \\
\hline Sunflower husk ash (SHA) & 29.3 & Demirbas A. et al. [14] \\
\hline Olive husk ash (OHA) & 32.7 & Demirbas A. et al. [14] \\
\hline Coconut shell ash (CSA) & 66.3 & Opeyemi J. et al. [15] \\
\hline Rape straw ash (RSA) & 36.7 & Masiá T.A.A. et al. [16] \\
\hline Eucalyptus biomass ash (EBA) & 1.2 & Teixeira A.H.C. [17] \\
\hline
\end{tabular}

The focus of numerous recent studies has been on investigating the possibility of RHA, POFA, CCA and SCSA application as cement substitutes in cement-based composites, especially RHA. The optimum combustion temperature for obtaining highly reactive RHA has been determined as $600{ }^{\circ} \mathrm{C}$ [18]; the finer RHA particles exhibit better pozzolanic activity and impart higher strength [19]; at least up to $10 \%$ cement replacement with RHA results in strength development comparable to the reference cement samples [20]; blending of cement with RHA leads to a denser microstructure, lower porosity and finer pore structure, thereby inhibiting the penetration of chlorides and chemical agents and improving durability properties of cement-based composites [21]. 
Few researchers have provided the information on far less utilized SCMs such as wheat straw ash [4,22-25], while the materials with lower pozzolanic activity, such as oil rapeseed ash, sunflower husk ash and soybean straw ash, have been investigated to a small extent.

It is estimated that the total potential of biomass from agriculture in Serbia is about 12.5 million tons per year. The analysis of the structure of biomass from the residues of agricultural production in Serbia indicates that more than half of the resources lies in corn biomass, more than a quarter in straw of cereals, and the rest of about $15 \%$ in harvest residues of sunflower, soybean, oilseed rape or residuals from orchards and vineyards.

Global wheat utilization in 2018/19 was forecast to reach almost 743 million tons [26]. Among the leading wheat producers worldwide, Serbia is listed at number 22-Figure 1, with the annual production of 2200 metric tons [27]. Based on the soybean seed production, Serbia is ranked at number 15 [28], with the annual production of 625 metric tons-Figure 2.

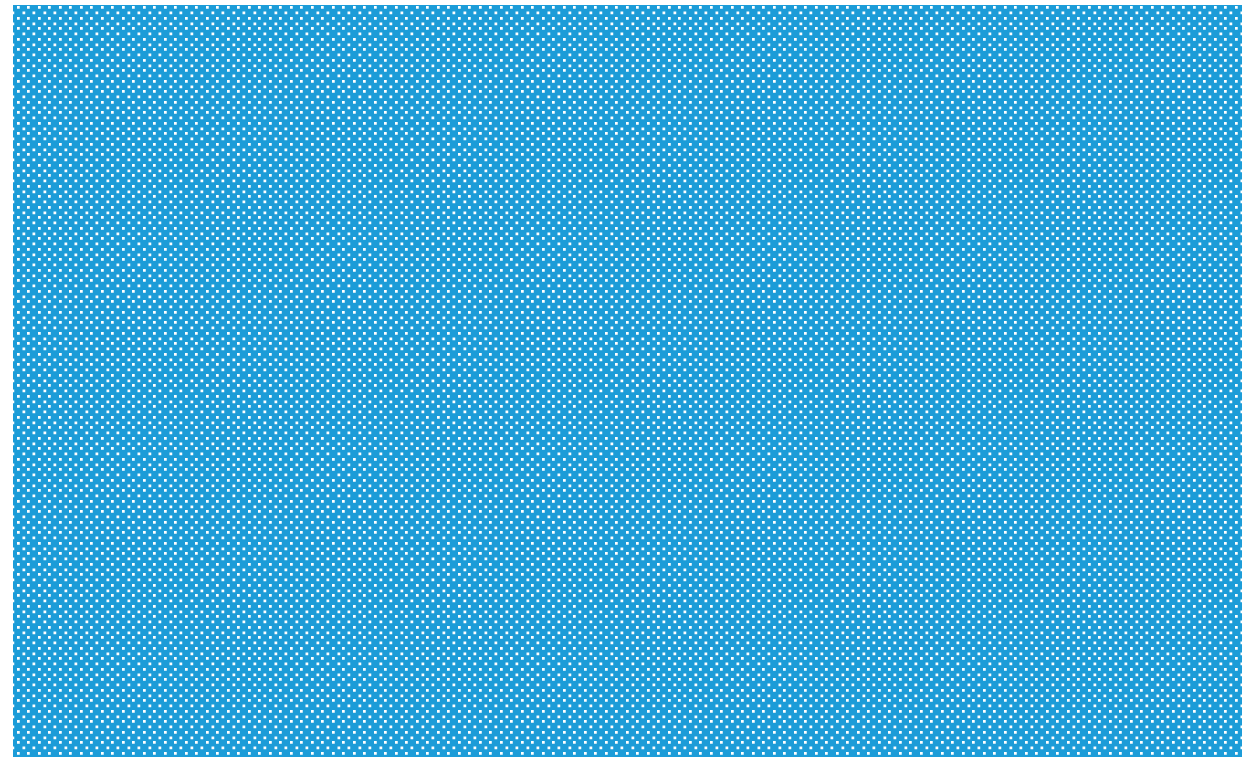

Figure 1. Global production of wheat, by country.

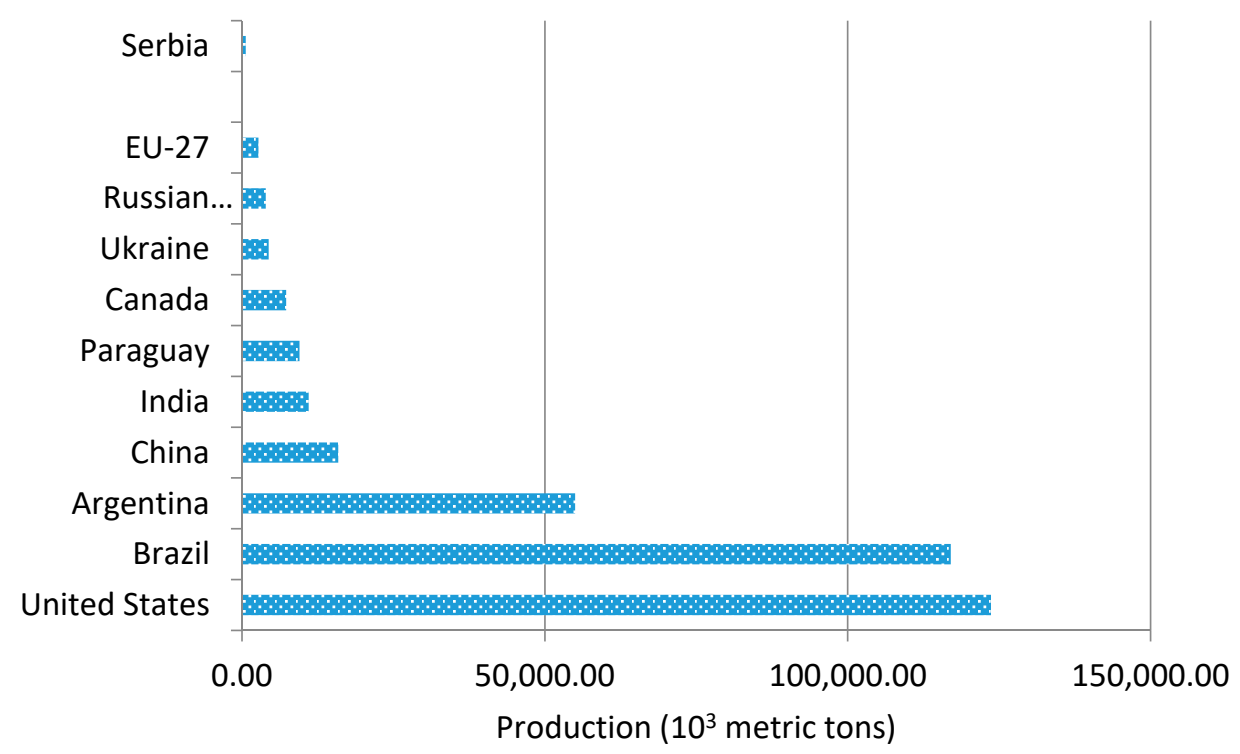

Figure 2. Global production of soybean seed, by country.

It is estimated that about half of harvest residues at large agricultural farms in Vojvodina can be used for energy purposes, while only about $20 \%$ generated on relatively 
small private farms is utilized by the same means. The main processes generating the energy obtained from biomass include direct combustion, pyrolysis, gasification, hydro gasification, liquefaction and alcoholic fermentation. Large amounts of biomass ash are created as waste products during these processes, estimated at 5000 tons per year. They are most commonly disposed of in landfills or recycled on agricultural fields. Considering that the disposal costs of biomass ashes and biomass ash volumes are ever-increasing, a sustainable ash management has to be established.

Biomass is the largest renewable energy source in the studied region, and Serbia belongs to the top of European countries by the amount of available, but unused biomass. Furthermore, domestic industry has already produced the equipment for biomass utilization. All this suggests that there is a good prospect for a larger use of biomass, but also for generating larger quantities of ash produced by its combustion.

The use of biomass ashes as SCMs in cement composites production in Serbia have been scarcely investigated so far. Previous studies, conducted mostly on cement mortars blended with WSA $[29,30]$, have documented that WSA blended mortar shows a promising performance in strength, depending on the level of fineness and chemical composition of the ash. However, very few studies have dealt with the microstructure and reactivity parameters of WSA as a pozzolanic material, while no studies referring to soybean strawbased ashes application can be found. In addition, locally available waste materials, originating from agriculture in Serbia, are explored and investigated for possible SCM application for the first time.

Therefore, the objectives of this study were to investigate the composition and reactivity of wheat and soybean straw-based ashes and explore the possibility of their application as pozzolanic materials in cementitious systems. Substituting cement in mortar and concrete with biomass ashes, as $\mathrm{CO}_{2}$ neutral fuel, would (1) reduce the negative impact of concrete industry on global warming, (2) provide a new use-value of ashes as a novel product and (3) offer the possibility of their economic valuation as such. With respect to the annually available quantities of biomass ashes in Serbia and taking into account that one ton of $\mathrm{CO}_{2}$ is emitted during the production of one ton of cement, a possible reduction of this pollutant in the case of managing all the generated waste in the studied region would be up to 5 million tons. All these effects would constitute a strong impetus for the creation of conditions allowing an integrated management of abundant waste materials originating from agriculture in Serbia.

\section{Materials and Methods}

\subsection{Materials}

\subsubsection{Cement}

Ordinary Portland cement (OPC), originating from Lafarge cement factory in Beočin, Serbia, was used. The cement has a specific gravity of $3.1 \mathrm{~g} / \mathrm{cm}^{3}$ and the Blaine fineness of $4.000 \mathrm{~cm}^{2} / \mathrm{g}$.

\subsubsection{Biomass Ashes}

Samples of biomass ashes: Wheat straw ash (WSA)—Figure 3a, mixture of wheat and soybean straw ash (WSSA) - Figure $3 \mathrm{~b}$ and soybean straw ash (SSA) - Figure $3 \mathrm{c}$, were collected from three different producers in Serbia: Agricultural enterprise Mitrosrem, the soybean processing factory Sojaprotein and polypropylene factory Hipol, respectively.

The ashes were roughly sieved, through a $4 \mathrm{~mm}$ sieve, in order to separate un-burnt straw and other large impurities.

In order to obtain a material with high specific surface area, ashes were further ground in a laboratory ball mill until the Blaine fineness reached the range of $5500-6000 \mathrm{~cm}^{2} / \mathrm{g}$ (grinding time $6 \mathrm{~h}$ ). 


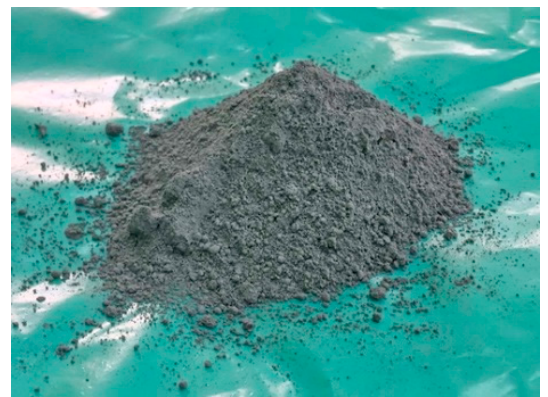

(a)

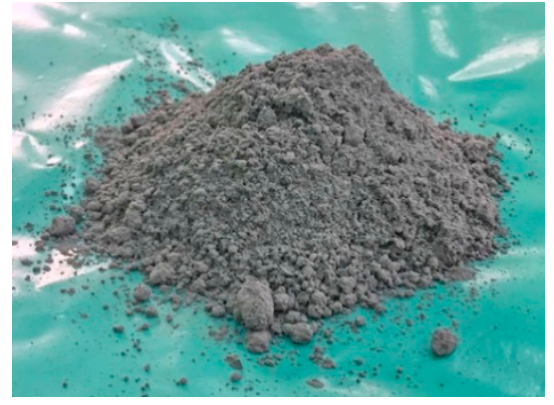

(b)

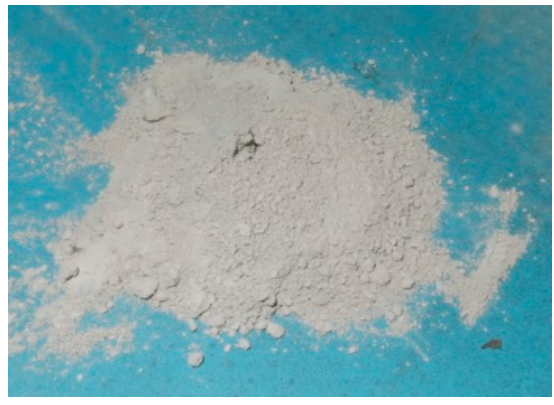

(c)

Figure 3. (a) Wheat straw ash, after sieving and grinding. (b) Mixture of wheat and soybean straw ash, after sieving and grinding. (c) Soybean straw ash, after sieving and grinding.

\subsubsection{Silica Fume}

A commercially available product-Silica fume-was used as an additive to improve the activity index of SSA. The silica fume has a specific gravity of $2.4 \mathrm{~g} / \mathrm{cm}^{3}$ and the amorphous silica content of cca $90 \%$.

\subsubsection{Fine Aggregate}

Standard CEN sand was used as fine aggregate for the preparation of cement pastes blended with biomass ashes.

\subsection{Methods}

Characterization of biomass ashes included several physical and chemical properties tests according to the relevant standards as well as the evaluation of the criteria conformity. The chemical composition of biomass ashes was determined using energy dispersive X-ray fluorescence spectrometer (EDXRF 2000 Oxford instruments, Belgrade, Serbia) according to EN 196-2, 2015 [31] and ISO 29581-2, 2010 [32]. The representative samples (100 g) were pulverized in a laboratory vibratory mill prior to the testing. The loss on ignition (LOI) was determined as a weight difference between $20^{\circ} \mathrm{C}$ and $950^{\circ} \mathrm{C}$.

Leaching of heavy metals from biomass ashes and cement was tested via method EPA 6010C:2000 (for heavy metals: As, Ba, Cd, Co, Cr, Cu, Mn, Mo, Ni, Pb, Sb, Sn and Zn), using ICP-OES-ICPE9820, Shimadzu, Kyoto, Japan and via method US EPA 7471B:2007 (for $\mathrm{Hg}$ ), applying AAS-(AA7000), Shimadzu, Kyoto, Japan. The preparation of test samples was carried out in accordance with EN 12457-2:2008 [33] using one stage batch test at a liquid-solid ratio of $10 \mathrm{l} / \mathrm{kg}$ for materials with particle size below $4 \mathrm{~mm}$ (without size reduction). The instrumentation employed within the test include: Analytical balance-XT 220A Precisa, Dietikon, Switzerland, Dryer-LSW-53 Vims Electronic, Tršić, Serbia and shaker-machine for testing samples by shaking Vekamer, Novi Sad, Serbia.

Specific surface area of biomass ashes was determined according to Blaine air permeability method given in EN 196-6, 2011 [34], which is widely used for characterizing Portland cement. The test is based on the principle of resistance to air flow through a partially compacted sample of cement, and is a single parameter that is meant to identify the fineness of a powder material.

Initial and final setting time, fineness and soundness of biomass ashes were determined in accordance with EN 196-3, 2010 [35]. The method is used for assessing whether the abovementioned physical properties of a SCM material are in conformity with the requirements given in EN 450-1 [36].

The pozzolanic activity was studied on samples prepared according to the procedure given in SRPS B.C1.018, 2015 [37]. Mortars were prepared with biomass ash, slaked lime and standard sand, with the following mass proportions: $\mathrm{m}_{\mathrm{sl}}: \mathrm{m}_{\mathrm{bash}}: \mathrm{m}_{\mathrm{qs}}=1: 2: 9$ and waterbinder ratio 0.6 (where: $\mathrm{m}_{\mathrm{sl}}$-mass of slaked lime; $\mathrm{m}_{\text {bash }}$-mass of biomass ash; $\mathrm{m}_{\mathrm{qs}}$ - mass of CEN standard sand). After compacting, the samples were hermetically sealed and 
cured for $24 \mathrm{~h}$ at $20^{\circ} \mathrm{C}$, then for 5 days at $55^{\circ} \mathrm{C}$. Subsequently, $24 \mathrm{~h}$ period was allowed for samples cooling process to reach $20^{\circ} \mathrm{C}$, followed by compressive and flexural strength tests.

The activity index of biomass ashes was examined according to EN 450-1, 2014 [36]. Activity index is defined as a ratio (in percent) of the compressive strength of standard mortar bars, prepared with $75 \%$ test cement plus $25 \%$ ash by mass, and the compressive strength of standard mortar bars prepared with $100 \%$ cement, when tested at the same age. The preparation of standard mortar bars and determination of the compressive strength were carried out in accordance with EN 196-1, 2018 [38].

Mineralogical composition was specified for all types of ashes using X-ray powder diffraction technique (XRD). XRD patterns were recorded on Philips PW1710 device, Belgrade, Serbia under the following experimental conditions: Monochromatic $\mathrm{Cu} \mathrm{K} \alpha$ radiation with $1.5418 \AA$ wavelength in $10-65^{\circ}$ of $2 \theta$ range, scan rate $0.02^{\circ}$ and 0.5 s per step, operating at $40 \mathrm{kV}, 30 \mathrm{~mA}$.

The functional groups in the ash samples were identified using Fourier TransformInfrared Spectrometer (Thermo-Nicolet Nexus 670 FTIR spectrometer, Belgrade, Serbia). The FTIR analysis was performed under the following experimental conditions: KBr pellet technique, spectral resolution of $4 \mathrm{~cm}^{-1}$, range of $4000-400 \mathrm{~cm}^{-1}$, 32-averaged scans per one measurement.

The behavior of the ashes towards high temperatures was investigated experimentally by means of Labsys Evo (Setaram) thermal analyzer using TGA-DSC, Novi Sad, Serbia (thermogravimetric analysis-differential scanning calorimetry) as a kind of simultaneous thermal analysis-STA. TGA analysis was carried out to obtain the weight loss and DSC to obtain phase change as a function of temperature. Differentiation of the thermogravimetric data (mass loss rate) allows a better resolution and identification of weight losses (DTG). During the experiment, the ash sample was placed in an alumina crucible whereas an empty one was used as a reference. The output information from each test was a change of sample mass (TGA), mass loss rate (DTG) and heat flow (DSC), as a function of temperature. The TGA-DTG-DSC measurements were performed in the temperature range $25-1000{ }^{\circ} \mathrm{C}$ with heating rate of $10 \mathrm{~K} / \mathrm{min}$ and in an argon atmosphere. The sample mass was about $40 \mathrm{mg}$.

\section{Test Results and Discussion}

\subsection{Chemical Analyses}

\subsubsection{Chemical Composition}

The results of testing the chemical composition of biomass ashes, including the reactive silicon dioxide content, the content of chloride, soluble phosphate content and the content of free calcium oxide are summarized in Table 2.

Table 2. Chemical composition of biomass ashes.

\begin{tabular}{|c|c|c|c|}
\hline & $\begin{array}{l}\text { Wheat Straw Ash } \\
\text { (WSA) }\end{array}$ & $\begin{array}{c}\text { Mixture of Wheat and } \\
\text { Soybean Straw Ash } \\
\text { (WSSA) }\end{array}$ & $\begin{array}{c}\text { Soybean Straw Ash } \\
\text { (SSA) }\end{array}$ \\
\hline Loss of ignition at $950^{\circ} \mathrm{C}$ & 5.18 & 4.85 & 10.73 \\
\hline Moisture loss at $105^{\circ} \mathrm{C}$ & 0.95 & 1.00 & 3.62 \\
\hline $\mathrm{SiO}_{2}, \%$ & 69.13 & 56.36 & 32.62 \\
\hline $\mathrm{Al}_{2} \mathrm{O}_{3}, \%$ & 1.12 & 2.03 & 4.58 \\
\hline $\mathrm{Fe}_{2} \mathrm{O}_{3}, \%$ & 0.73 & 1.53 & 1.46 \\
\hline $\mathrm{Na}_{2} \mathrm{O}, \%$ & 0.11 & 0.20 & 0.85 \\
\hline $\mathrm{K}_{2} \mathrm{O}, \%$ & 13.03 & 20.02 & 20.96 \\
\hline $\mathrm{MgO}, \%$ & 2.5 & 3.54 & 8.33 \\
\hline $\mathrm{CaO}, \%$ & 5.78 & 7.13 & 15.78 \\
\hline $\mathrm{SO}_{3}, \%$ & 0.2 & 0.18 & 0.47 \\
\hline $\mathrm{P}_{2} \mathrm{O}_{5}, \%$ & 1.72 & 3.72 & 3.72 \\
\hline Soluble $\mathrm{P}_{2} \mathrm{O}_{5}, \mathrm{mg} / \mathrm{kg}$ & 13.77 & 115.95 & $<0.05$ \\
\hline Content $\mathrm{Cl}^{-}, \%$ & 0.060 & 0.025 & 0.127 \\
\hline Free $\mathrm{CaO}$ content, $\%$ & 0.14 & 0.28 & 0.39 \\
\hline $\begin{array}{c}\text { Reactive } \mathrm{SiO}_{2} \\
\text { content, } \%\end{array}$ & 67.07 & 40.99 & 24.93 \\
\hline
\end{tabular}


Summarized results of chemical properties of biomass ashes, requirements in relevant standards, as well as criteria fulfillment are given in Table 3.

Table 3. Chemical composition of biomass ashes-criteria fulfillment.

\begin{tabular}{|c|c|c|c|c|c|c|}
\hline & $\begin{array}{l}\text { Chemical Requirements } \\
\text { (EN 450-1) }\end{array}$ & Criteria & Standard & WSA & WSSA & SSA \\
\hline \multirow{9}{*}{ 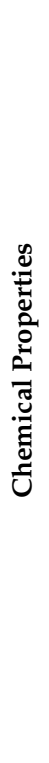 } & $\begin{array}{c}\text { Total amount of oxides: } \\
\mathrm{SiO}_{2}+\mathrm{Al}_{2} \mathrm{O}_{3}+\mathrm{Fe}_{2} \mathrm{O}_{3}(\%)\end{array}$ & $\geq 70 \%$ & $\begin{array}{l}\text { EN 196-2 } \\
\text { EN 450-1 }\end{array}$ & 71.0 & 57.12 & 39.04 \\
\hline & Loss of ignition (\%) & $\begin{array}{l}\text { A: } \operatorname{Max} 5 \% \\
\text { B: } \operatorname{Max} 7 \% \\
\text { C: } \operatorname{Max} 9 \%\end{array}$ & $\begin{array}{l}\text { EN 196-2 } \\
\text { EN 450-1 }\end{array}$ & $\begin{array}{l}5.1 \\
\text { CLASS B }\end{array}$ & $\begin{array}{c}4.85 \\
\text { CLASS A }\end{array}$ & 10.93 \\
\hline & Chloride content (\%) & $\leq 0.1 \%$ & $\begin{array}{l}\text { EN 196-2 } \\
\text { EN 450-1 }\end{array}$ & 0.060 & 0.025 & 0.127 \\
\hline & Sulphate content (\%) & $\leq 3 \%$ & $\begin{array}{l}\text { EN 196-2 } \\
\text { EN 450-1 }\end{array}$ & 0.2 & 0.18 & 0.47 \\
\hline & Free $\mathrm{CaO}$ content $(\%)$ & $\leq 1.5 \%$ & $\begin{array}{l}\text { EN451-1 } \\
\text { EN } 450-1\end{array}$ & 0.14 & 0.28 & 0.39 \\
\hline & Reactive $\mathrm{SiO}_{2}$ content (\%) & $\geq 25 \%$ & $\begin{array}{l}\text { EN197-1 } \\
\text { EN 450-1 }\end{array}$ & 67.07 & 40.99 & 24.93 \\
\hline & $\begin{array}{l}\text { Total amount of alkalis (\%) } \\
\qquad \mathrm{Na}_{2} \mathrm{O}+0.658 \mathrm{~K}_{2} \mathrm{O}\end{array}$ & $\leq 5 \%$ & $\begin{array}{l}\text { EN 196-2 } \\
\text { EN 450-1 }\end{array}$ & 8.68 & 13.37 & 14.64 \\
\hline & Phosphate content (\%) & $\leq 5 \%$ & $\begin{array}{l}\text { ISO 29581-2 } \\
\text { EN 450-1 }\end{array}$ & 1.72 & 3.72 & 3.72 \\
\hline & $\begin{array}{l}\text { Soluble phosphate content } \\
(\mathrm{mg} / \mathrm{kg})\end{array}$ & $\leq 100 \mathrm{mg} / \mathrm{kg}$ & EN 450-1 & 13.8 & 116 & 0.05 \\
\hline
\end{tabular}

The pozzolanic activity of materials depends mainly on the amount of oxides: $\mathrm{SiO}_{2}$, $\mathrm{Al}_{2} \mathrm{O}_{3}$ and $\mathrm{Fe}_{2} \mathrm{O}_{3}$, the ratio between them and their reactivity. These compounds are responsible for improving the mechanical properties of the mix, due to the increasing development of pozzolanic reactions and formation of C-S-H products over time. Total amount of these oxides, according to EN 450-1 [36], should exceed 70\%. Only WSA fulfills this requirement, while soybean-based ashes have insufficient amount of these oxides, which is expected to reflect on their pozzolanic activity.

Loss of ignition of WSA and WSSA is lower than 7\% and $5 \%$, hence these ashes fulfill the criteria for category B and A, respectively. This chemical property of SSA exceeds the limit value for all classes, which could be attributed to a higher organic content of this type of biomass ash.

The condition of passivity (high $\mathrm{pH}$ value) of cement-based material can be threatened due to the process of absorbing chloride ions, hence their content is limited to max $0.1 \%$. WSA and WSSA fulfill this criterion, while SSA exceeds the indicated value.

An excessive amount of sulphates leads to an expansive effect-the formation of secondary ettringite [39], which may cause disintegration of the matrix of cement-based composite or its cracking, both leading to a reduction in overall strength of the element. All types of biomass ashes used in the research are characterized by a low amount of sulphates, satisfying the criterion defined by the given standards $(\leq 3 \%)$.

Free lime can cause a delayed expansion and compressive strength reduction of cement-based composites, which could result in a serious deterioration of structures built [40]. All biomass ashes used in this study have low quantities of free lime.

Reactive silica is the key parameter that determines the pozzolanic potential of a material, i.e., its tendency to react with available calcium hydroxide to form cementitious hydration products. WSA has a relatively high amount of reactive silica, exceeding $67 \%$. With the increase of soybean straw ash, silica content decreases. WSSA has a satisfactory amount, while the amount of silica in SSA is slightly below the required value.

Alkali-silica reaction (ASR) is the reaction between alkaline cement paste and amorphous silica, which is found in many common aggregates. This reaction produces swelling 
gel products which lead to an expansive pressure inside concrete and its cracking. In order to mitigate ASR, the alkali metal contents of the cement are limited to $5 \%$ (total alkali content). Results indicate that all types of biomass ashes are characterized by high alkali content, especially soybean-based ashes. In order to mitigate ASR, some authors suggest water treatment of raw ash as an effective way to eliminate the negative effects of high alkali content [22]. Nevertheless, non-reactive aggregates (in a crystalline form) can be used in the presence of high alkali biomass ashes.

The major effect of phosphate is to decrease alite/belite ratio, with a strong deterioration of the mechanical properties of the hydrated cement, since alite is the main hydraulic phase in clinker [41]. Phosphates, in the presence of moisture, tend to form phosphoric acid, which reduces the $\mathrm{pH}$ value of cement, causes corrosion of reinforcement in concrete and decelerates the disintegration of cement materials. The total phosphate content of the tested biomass ashes is within limit values, while the soluble phosphate content exceeds this figure in WSSA.

\subsubsection{Heavy Metals}

The use of waste products as compost is subject to a common peculiarity of legislative restrictions and standards with respect to the environmental and soil conservation aspects. These restrictions play an essential role in the process of evaluating the possibility of using biomass ashes for agricultural purposes, at the same time having regard to the beneficial effects of compost. Table 4 shows heavy metal content in biomass ashes and cement and the limit values given for the use of waste materials in agriculture, in accordance with Working group Compost—Consulting and Development [42].

Table 4. Heavy metal content in the tested biomass ashes, cement and the limit values given for the use of waste materials in agriculture.

\begin{tabular}{lccccc}
\hline & WSA & WSSA & SSA & Cement & Limit Value \\
\hline $\mathrm{As}, \mathrm{mg} / \mathrm{kg}$ & 0.03 & 0.03 & 0.03 & 0.03 & 200 \\
\hline $\mathrm{Ba}, \mathrm{mg} / \mathrm{kg}$ & 407.00 & 325.01 & 225.01 & 263 & - \\
\hline $\mathrm{Cd}, \mathrm{mg} / \mathrm{kg}$ & 0.03 & 0.03 & 0.03 & 0.03 & 0.7 \\
\hline $\mathrm{Co}, \mathrm{mg} / \mathrm{kg}$ & 0.01 & 0.01 & 0.01 & 0.01 & - \\
\hline $\mathrm{Cr}, \mathrm{mg} / \mathrm{kg}$ & 71.25 & 87.25 & 67.50 & 97 & 70 \\
\hline $\mathrm{Cu}, \mathrm{mg} / \mathrm{kg}$ & 84.25 & 107.75 & 172.52 & 0.01 & 70 \\
\hline $\mathrm{Hg}, \mathrm{mg} / \mathrm{kg}$ & 0.01 & 0.01 & 0.01 & 0.01 & 0,4 \\
\hline $\mathrm{Mn}, \mathrm{mg} / \mathrm{kg}$ & 500.00 & 587.01 & 335.12 & 470 & - \\
\hline $\mathrm{Mo}, \mathrm{mg} / \mathrm{kg}$ & 0.01 & 0.01 & 0.01 & 0.01 & - \\
\hline $\mathrm{Ni}, \mathrm{mg} / \mathrm{kg}$ & 0.01 & 0.01 & 0.01 & 0.01 & 25 \\
\hline $\mathrm{Pb}, \mathrm{mg} / \mathrm{kg}$ & 0.01 & 0.01 & 0.01 & 0.01 & 45 \\
\hline $\mathrm{Sb}, \mathrm{mg} / \mathrm{kg}$ & 0.03 & 12.50 & 335.01 & 0.05 & - \\
\hline $\mathrm{Sn}, \mathrm{mg} / \mathrm{kg}$ & 0.05 & 0.05 & 0.05 & 0.05 & - \\
\hline $\mathrm{Zn}, \mathrm{mg} / \mathrm{kg}$ & 5.00 & 37.50 & 51.25 & 150 & 200 \\
\hline
\end{tabular}

As follows from the figures shown above, tested biomass ashes satisfy the criteria for the use in agriculture regarding the levels of $\mathrm{As}, \mathrm{Cd}, \mathrm{Cu}, \mathrm{Ni}, \mathrm{Pb}$ and $\mathrm{Zn}$. These concentrations are in the same range as those of cement, with the exception of $\mathrm{Zn}$ content, which is significantly lower in relation to the cement. The levels of $\mathrm{Cr}$ and $\mathrm{Cu}$ exceed the limit values for WSA and WSSA samples, while SSA meets the criterion for Cr level and exceeds the limit for $\mathrm{Cu}$ content. Therefore, the SSA sample satisfies all the requirements for its use in agriculture, with the exception of $\mathrm{Cu}$ content. 
For the purpose of toxicity assessment of biomass ashes, in the context of these concentrations, a heavy metal index was calculated as the ratio of heavy metal content and the limit values for toxic elements. The results are given in Table 5.

Table 5. Heavy metal index-HMI for the use of waste materials in agriculture.

\begin{tabular}{ccccc}
\hline & WSA & WSSA & SSA & Cement \\
\hline $\mathrm{As}, \mathrm{mg} / \mathrm{kg}$ & 0.00 & 0.00 & 0.00 & 0.00 \\
\hline $\mathrm{Cd}, \mathrm{mg} / \mathrm{kg}$ & 0.00 & 0.00 & 0.00 & 0.00 \\
\hline $\mathrm{Cr}, \mathrm{mg} / \mathrm{kg}$ & 1.02 & 1.25 & 0.96 & 1.39 \\
\hline $\mathrm{Cu}, \mathrm{mg} / \mathrm{kg}$ & 1.20 & 1.54 & 2.51 & 0.00 \\
\hline $\mathrm{Hg}, \mathrm{mg} / \mathrm{kg}$ & 0.00 & 0.00 & 0.00 & 0.00 \\
\hline $\mathrm{Ni}, \mathrm{mg} / \mathrm{kg}$ & 0.00 & 0.00 & 0.00 & 0.00 \\
\hline $\mathrm{Pb}, \mathrm{mg} / \mathrm{kg}$ & 0.00 & 0.00 & 0.00 & 0.00 \\
\hline $\mathrm{Zn}, \mathrm{mg} / \mathrm{kg}$ & 0.025 & 0.187 & 0.26 & 0.75 \\
\hline $\mathrm{HMI} \mathrm{sum}$ & 2.245 & 2.98 & 3.73 & 2.14 \\
\hline
\end{tabular}

The heavy metal index is an indicator of waste material quality from the aspect of its toxicity. WSA is characterized with HMI close to that of cement. With the increase of soybean ash content, total HMI increases, which can mainly be attributed to a higher concentration of $\mathrm{Cu}$ in soybean-based ashes.

\subsubsection{Leaching of Heavy Metals}

Biomass ashes most commonly remain unutilized and are disposed of in a surrounding environment posing a threat to nearby ecosystems. The leaching of different heavy metals from biomass ashes could lead to a potential soil and groundwater contamination, hence the appropriate leaching test needed to be conducted. The leaching values were calculated at liquid-solid ratio $\mathrm{L} / \mathrm{S}=10 \mathrm{~L} / 1 \mathrm{~kg}$ (Table 6).

Table 6. Leaching of heavy metals from biomass ashes in $\mathrm{mg} / \mathrm{kg}$ ds (dry substance).

\begin{tabular}{ccccccccc}
\hline & $\mathbf{P b}$ & $\mathbf{C d}$ & $\mathbf{Z n}$ & $\mathbf{C u}$ & $\mathbf{N i}$ & $\mathbf{C r}$ & $\mathbf{H g}$ & As \\
\hline WSA & $<0.07$ & 0.27 & $<0.4$ & 0.36 & $<0.1$ & 0.44 & $<0.003$ & $<0.15$ \\
\hline WSSA & $<0.07$ & 0.22 & $<0.4$ & 1.5 & 0.13 & 0.62 & 0.01 & $<0.15$ \\
\hline SSA & $<0.07$ & 0.25 & $<0.4$ & 0.84 & $<0.1$ & 1.70 & $<0.003$ & $<0.15$ \\
\hline
\end{tabular}

These values were compared with limit values for waste materials on the landfill which are prescribed in Council Directive [43]. These limit values are given in Table 7.

Table 7. Leaching limit values of heavy metals, in $\mathrm{mg} / \mathrm{kg}$ ds.

\begin{tabular}{ccccccccc}
\hline & $\mathbf{P b}$ & $\mathbf{C d}$ & $\mathbf{Z n}$ & $\mathbf{C u}$ & $\mathbf{N i}$ & $\mathbf{C r}$ & $\mathbf{H g}$ & $\mathbf{A s}$ \\
\hline Inert & 0.5 & 0.04 & 4 & 2 & 0.4 & 0.5 & 0.01 & 0.5 \\
\hline Non-Hazardous & 10 & 1 & 50 & 50 & 10 & 10 & 0.2 & 2 \\
\hline Hazardous & 50 & 5 & 200 & 100 & 40 & 70 & 2 & 25 \\
\hline
\end{tabular}

Generally, all types of tested biomass ashes are characterized with no significant leaching values of heavy metals. Pursuant to the given criteria, all of them are classified as inert materials according to the content of $\mathrm{Pb}, \mathrm{Zn}, \mathrm{Cu}, \mathrm{Ni}, \mathrm{Hg}$ and $\mathrm{As}$ and non-hazardous materials based on the leaching of Cd. WSA is also classified as inert due to the content of 
Cr. Furthermore, with the rise of soybean straw ash content, the leaching of $\mathrm{Cr}$ increases. Thereby, WSSA and SSA belong to the group of non-hazardous materials.

\subsubsection{TGA/DSC}

The results obtained by TGA-DTG and DSC measurements for the ashes used in the study are presented in Figures 4 and 5, respectively.

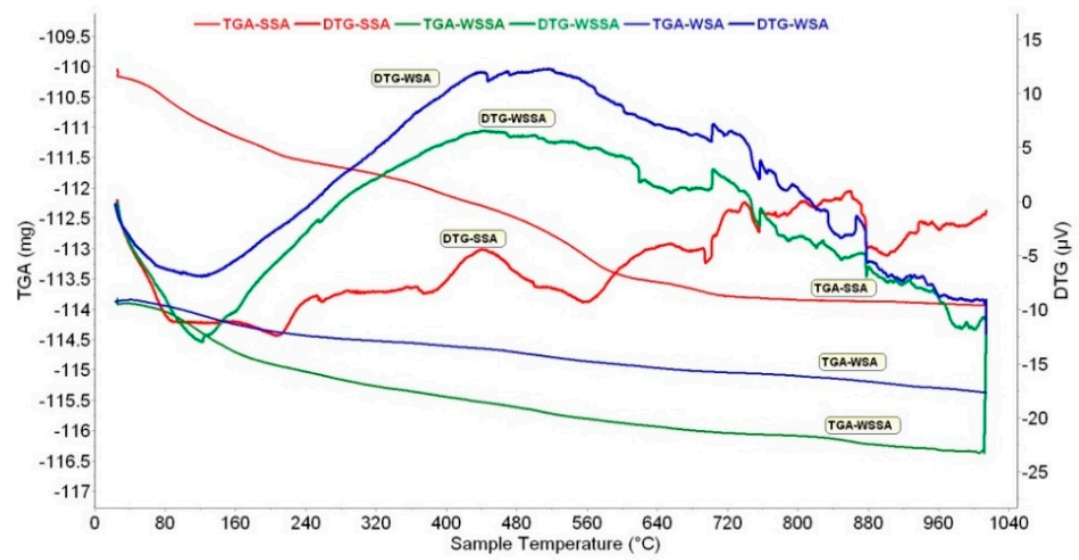

Figure 4. Results of TGA-DTG.

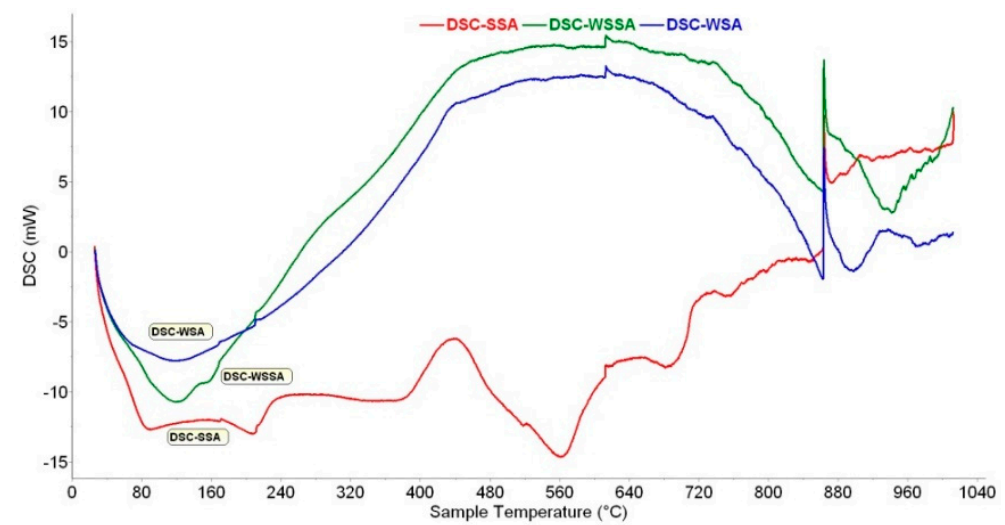

Figure 5. Results of DSC.

Based on STA measurements, the thermal process can be divided into three stages: (1) Moisture evaporation $\left(25-300^{\circ} \mathrm{C}\right),(2)$ decomposition and volatilization $\left(300-600{ }^{\circ} \mathrm{C}\right)$ and (3) continuous mineral decomposition $\left(600-1000{ }^{\circ} \mathrm{C}\right)$.

The mass changes and broad endothermic peaks (DSC and DTG) up to $300{ }^{\circ} \mathrm{C}$ are generally assumed to be evaporation processes of physically and chemically bound water [44]. The mass loss that can be attributed to this process is: $1.60 \%$ for WSA, 3.28\% for WSSA and $3.85 \%$ for SSA. These results are in good agreement with the results obtained using XRF and FTIR, confirming that SSA has the highest hygroscopicity and WSA the lowest (Table 2).

There are two likely interpretations for the occurrence of the observed exothermic peak in DSC or DTG curve between 300 and $\sim 600^{\circ} \mathrm{C}$ : (1) The volatilization of unburnt carbon and other organic matter present as a result of incomplete combustion; this was observed by Esteves at al [45], confirming the lower efficiency of the combustion process in the thermal power plant the biomass fly ash was collected at and (2) phosphorus oxide [46]. The weight loss in this range is $1.05 \%, 1.66 \%$ and $4.29 \%$ for WSA, WSSA and SSA, respectively. SSA has the highest value, thus explaining its highest loss on ignition given in Table 2. Moreover, the endothermic peak, visible only in SSA, centered at about $560{ }^{\circ} \mathrm{C}$, may correspond with calcium carbonate decomposition [47]. 
In the next range $600-850{ }^{\circ} \mathrm{C}$, the observed endothermic peaks probably correspond to the decomposition of carbonates and release of $\mathrm{CO}_{2}$ [44,48]. The mass loss in this interval is $0.61 \%$ for WSA, $0.71 \%$ for WSSA and $1.04 \%$ for SSA. The presence of increasing amounts of alkali components can decrease the decomposition temperature of $\mathrm{CaCO}_{3}$ [47], like in the case of SSA.

The mass losses observed at higher temperatures are mainly attributed to the evaporation of alkali-containing components. Therefore, the reduction in mass noted in the temperature segment $850-1000{ }^{\circ} \mathrm{C}$ characterized by the endothermic DSC peak (especially in SSA) is likely to be assigned to $\mathrm{KCl}$ evaporation, $\mathrm{K}_{2} \mathrm{CO}_{3}$ decomposition [44] or formation of $\mathrm{SO}_{2}$ [49]—reduction of sulfates or melting.

DTG curves of WSA and WSSA start bending down rapidly after $\sim 700{ }^{\circ} \mathrm{C}$, showing the initiation of a melting effect among the ash constituents [50].

The total mass losses from room temperature to $1000{ }^{\circ} \mathrm{C}$ are: $3.77 \%$ for WSA, $6.13 \%$ for WSSA and $9.35 \%$ for SSA. The mass losses of tested ashes at different temperature intervals are given in Table 8 . These percentages were calculated with respect to the initial mass of samples.

Table 8. The mass losses (\%) of ash at different temperature intervals.

\begin{tabular}{cccccc}
\hline Biomass Ash/Temperature & $\mathbf{2 5 - 3 0 0}{ }^{\circ} \mathbf{C}$ & $\mathbf{3 0 0 - 6 0 0}{ }^{\circ} \mathbf{C}$ & $\mathbf{6 0 0 - 8 5 0}{ }^{\circ} \mathbf{C}$ & $\mathbf{8 5 0 - 1 0 0 0}{ }^{\circ} \mathbf{C}$ & Total \\
\hline WSA & 1.6 & 1.05 & 0.61 & 0.51 & 3.77 \\
\hline WSSA & 3.28 & 1.66 & 0.71 & 0.48 & 6.13 \\
\hline SSSA & 3.85 & 4.29 & 1.04 & 0.17 & 9.35 \\
\hline
\end{tabular}

A discrepancy in weight loss results obtained using LOI and TGA could be attributed to an incomplete decomposition of all species.

\subsubsection{FTIR}

FTIR spectrograph shown in Figure 6 was observed in order to identify functional groups present in the tested ashes. The broad peak at about $3400 \mathrm{~cm}^{-1}$ (characteristic of all three samples) is allocated to the $\mathrm{OH}$-stretching vibration of adsorbed water bands whereas the one at $1630 \mathrm{~cm}^{-1}$ is associated to the $\mathrm{OH}$-bending vibration in $\mathrm{H}_{2} \mathrm{O}$ molecules [51]. Also, several peaks in the range $3400-4000 \mathrm{~cm}^{-1}$ may be assigned to absorbed water. These peaks are the most intense for SSA, which coincides with the results obtained by other analyses.

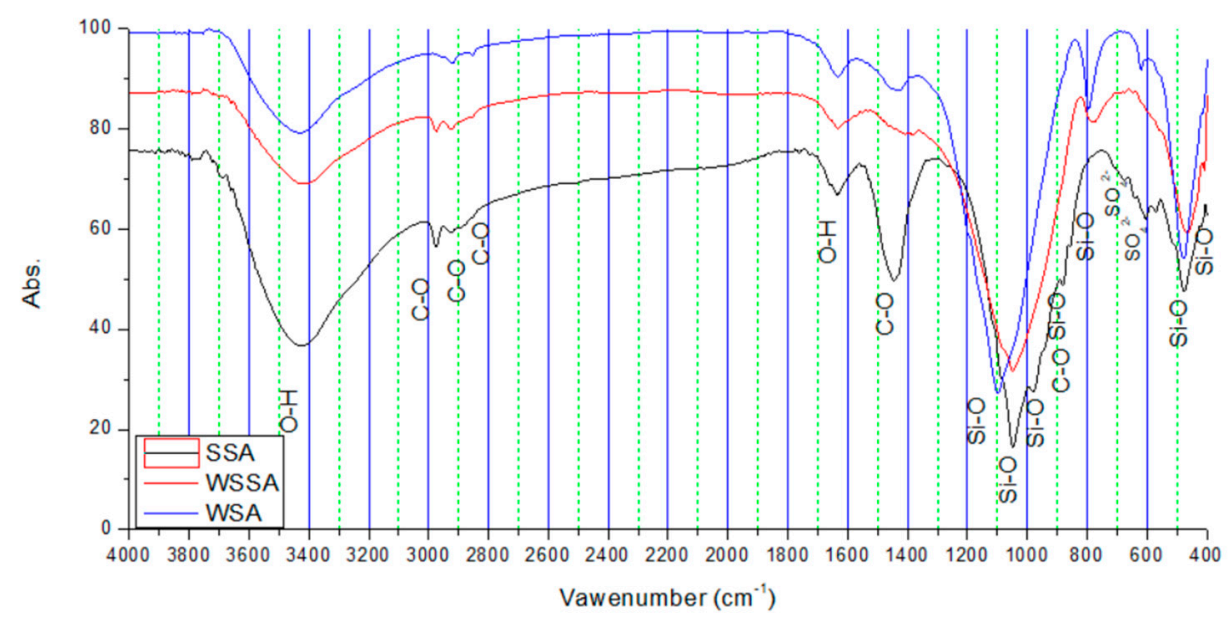

Figure 6. FTIR spectra of tested biomass ashes.

The peaks appearing in the region $2920-2925 \mathrm{~cm}^{-1}$ in all the samples show the presence of organic carbon [52]. These peaks are particularly pronounced in SSA. 
A spectral band between 1380 and $1450 \mathrm{~cm}^{-1}$ is characteristic of the asymmetric stretching vibration of $\mathrm{C}=0$ group, which suggests the presence of carbonate compounds in the samples $[53,54]$. The band at $1447 \mathrm{~cm}^{-1}$, distinctive in SSA, has the highest intensity and it is typical for alkaline carbonates [54].

The most intense band observed for all ashes is at approximately $1000-1100 \mathrm{~cm}^{-1}$, and is attributed to the asymmetric stretching vibrations of $\mathrm{Si}(\mathrm{Al})-\mathrm{O}$ in silica and aluminosilicate phases $[55,56]$. This band provides information on the degree of crystallinity/amorphicity of a sample [57]. The interpretation of the FTIR spectra in this range may be very difficult because the bond vibrations tend to overlap. The broad band in this range, which is the most intensive in the WSA sample, is suggested to be related to an amorphous aluminosilicate phase [58]. Al/Si ratio increases with the decreasing wavenumber values, as in the case of WSSA and SSA in relation to WSA.

The band detected at $979.96 \mathrm{~cm}^{-1}$ in SSA is mainly associated with the stretching vibration of Si-O-Si(Al) $[59,60]$ while the peak appearing at around $880 \mathrm{~cm}^{-1}$, corresponds to $\mathrm{CO}^{3-}$ ion (carbonated ion, probably potassium carbonate) [61-64].

The band at $794.86 \mathrm{~cm}^{-1}$ which is visible in WSA and the band at $776.81 \mathrm{~cm}^{-1}$ visible in WSSA are due to the Si-O-Si stretching vibration (probably cristobalite and quartz) [64-66]. This band is not detected in SSA. Also, the band situated at $620 \mathrm{~cm}^{-1}$ in WSA signifies the presence of cristobalite phase, which was also observed in the biomass ash examined by Osman et al. [67]. The presence of calcium sulfate in the form of anhydrite may be confirmed by the vibration band appearing at $604 \mathrm{~cm}^{-1}$, typically found in SSA [57].

The band at $570.61 \mathrm{~cm}^{-1}$ visible only in SSA comes from Al-O-SI vibration (mullite), as noted by Cretescu et al. [64,68].

The band values under $500 \mathrm{~cm}^{-1}$ characteristic for all samples indicate the presence of the Si-O functional group [69]. The peaks near $466 \mathrm{~cm}^{-1}$ in WSSA correspond probably to a mode of feldspar [52].

\subsubsection{X-ray Diffraction}

The X-ray diffractogram of tested biomass ashes is shown in Figure 7 and it was taken to determine the crystalline phases present in the ashes. WSA comprises amorphous phases (major part) as indicated by a characteristic broad hump from $17^{\circ}$ to $35^{\circ}(2 \theta)$. The main crystalline components of this ash are cristobalite and quartz (both are $\mathrm{SiO}_{2}$ ). The peaks of cristobalite are the most intensive. A similar result was obtained for WSSA but with the hump from $20^{\circ}$ to $35^{\circ}(2 \theta)$ and a lower intensity of peaks corresponding to cristobalite and quartz. Cristobalite in amorphous form is also specific for wheat husk ash examined by Hernández-Martínez et al. [66]. Feldspar and calcite were also observed in WSSA.

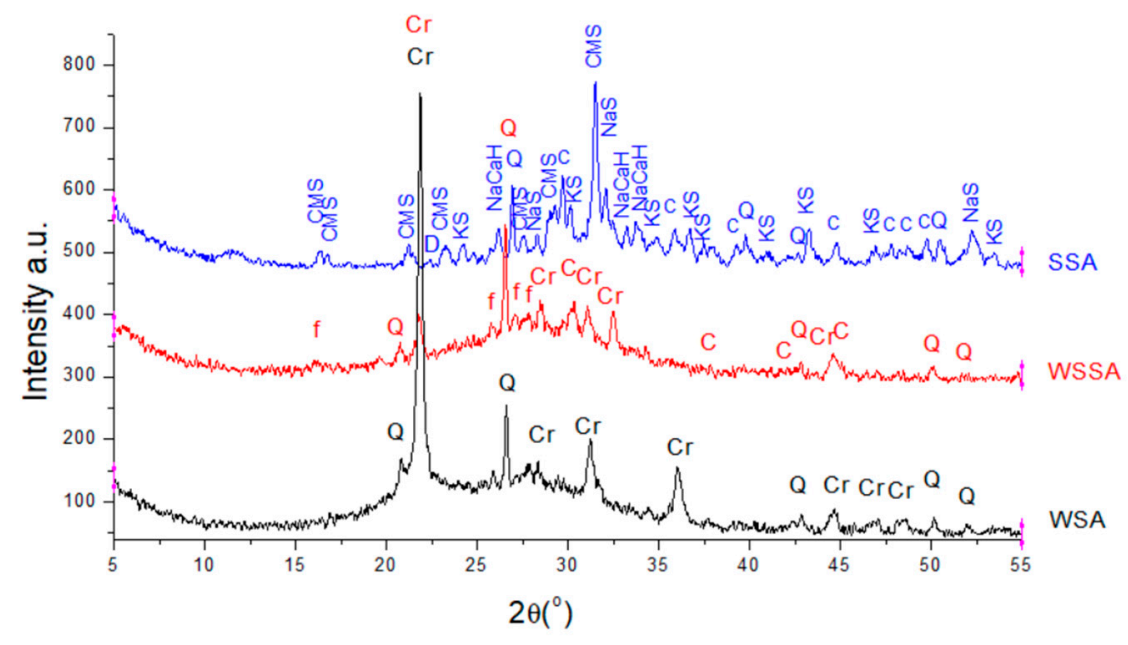

Figure 7. XRD pattern of biomass ashes (Q-quartz, Cr-cristobalite, f-feldspar-like minerals, C-calcite, CMS-calcium magnesium silicate, NaS-sodium sulphate, KS-potasium sulphate, NaCaH-sodium calcium hydrogen, D-dolomite). 
The intensity of phase diffraction peaks is proportional to the concentration of components influencing it; likewise, the difference in peak phase intensities symbolizes the difference in the concentration of phase constituents. It is known that amorphous silica, being more reactive than crystalline silica, is preferred for pozzolanic reaction [70]. The high silica content in amorphous state (especially in WSA) gives ashes the potential for use as a pozzolanic material in cement-based mixtures.

The XRD pattern of SSA shows a large number of small diffraction peaks: Predominantly silicate, related to quartz, sulphate in a form of sodium and potassium sulphate, magnesium as dolomite and calcium magnesium silicate as well as carbonate associated with calcite and dolomite. According to the size of hump, this type of biomass ashes has fewer amorphous phases centered at about $32^{\circ}(2 \theta)$ than WSA and WSSA.

\subsection{Physical Properties of Biomass Ashes}

Physical properties of tested biomass ashes are shown in Table 9.

Table 9. Physical properties of tested biomass ashes.

\begin{tabular}{ccc}
\hline & Specific Gravity $\left(\mathbf{k g} / \mathbf{m}^{3}\right)$ & Specific Surface Area (Blaine) $\left(\mathbf{c m}^{2} / \mathbf{g}\right)$ \\
\hline WSA & 2380 & 5800 \\
\hline WSSA & 2370 & 5500 \\
\hline SSA & 2400 & 5600 \\
\hline
\end{tabular}

All types of ashes have similar specific gravities, cca $2400 \mathrm{~kg} / \mathrm{m}^{3}$. After grinding in a laboratory ball mill for $6 \mathrm{~h}$, specific surface area (Blaine) of biomass ashes reached $5500 \mathrm{~cm}^{2} / \mathrm{g}$.

\subsection{Pozzolanic Activity}

Pozzolanic material class was determined based on 7-day compressive $\left(f_{c}\right)$ and flexural $\left(\mathrm{f}_{\mathrm{f}}\right)$ strength of standard mortar prisms. Results revealing the pozzolanic properties of tested biomass ashes are given in Table 10.

Table 10. Pozzolanic activity of tested biomass ashes.

\begin{tabular}{|c|c|c|c|c|c|c|c|}
\hline $\begin{array}{c}\text { Biomass } \\
\text { Ash }\end{array}$ & $\begin{array}{c}\mathbf{f}_{\mathrm{f}, \mathrm{av}} \\
(\mathrm{MP})]\end{array}$ & $\begin{array}{c}\mathbf{f}_{\mathrm{f}, \min } \\
(\mathbf{M P a})\end{array}$ & $\begin{array}{c}\text { Flexural } \\
\text { Strength } \\
\text { Class }\end{array}$ & $\begin{array}{c}\mathbf{f}_{\mathrm{c}, \mathrm{av}} \\
(\mathrm{MPa})\end{array}$ & $\begin{array}{c}\mathbf{f}_{\mathrm{c}, \min } \\
(\mathbf{M P a})\end{array}$ & $\begin{array}{l}\text { Compressive } \\
\text { Strength } \\
\text { Class }\end{array}$ & Class \\
\hline WSA & 3.4 & 3.3 & 10 & 11.0 & 10.3 & 10 & 10 \\
\hline WSSA & 3.6 & 3.3 & 10 & 9.3 & 8.75 & 5 & 5 \\
\hline SSA & 1.6 & 1.45 & / & 4.06 & 3.84 & / & / \\
\hline
\end{tabular}

As can be seen from the figures shown above, WSA displays a pozzolanic activity of Class 10, WSSA demonstrates a pozzolanic activity of Class 5, while SSA, manifests an insufficient activity to achieve this type of class. The achieved class of pozzolanic activity of biomass ashes, as potential pozzolanic materials, primarily depends on the amount of reactive silica. As the amount of soybean straw increases, reactive silica content is reduced and the class of pozzolanic activity decreases. This is a direct consequence of a lower amount of reactive silica in soybean-based biomass ashes, as discussed in previous chapters.

\subsection{Setting Time}

The initial setting time, as specified in EN 197-1 [70], shall not be more than twice as long as the initial setting time of a $100 \%$ (by mass) reference cement paste (criterion 1 ). The initial setting time, should not be shorter than 60 minutes-criterion 2 (for cement type 
CEM I 42,5R). All types of tested biomass ashes fulfill these criteria. The results are given in Table 11.

Table 11. Initial and final setting time of biomass ashes.

\begin{tabular}{cccll}
\hline & $\begin{array}{c}\text { The Initial Setting } \\
\text { Time (Minutes) }\end{array}$ & $\begin{array}{c}\text { The Final Setting } \\
\text { Time (Minutes) }\end{array}$ & Criterion $\mathbf{1}$ & Criterion 2 \\
\hline C & 230 & 275 & fulfilled & fulfilled \\
\hline WSA & 220 & 320 & fulfilled & fulfilled \\
\hline WSSA & 350 & 420 & fulfilled & fulfilled \\
\hline SSA & 310 & 355 & fulfilled & fulfilled \\
\hline
\end{tabular}

The addition of WSA did not retard the initial setting time, as expected when it comes to SCMs; instead, the presence of this ash slightly accelerated it. As the hydration process of a pozzolanic material takes longer time and retards the setting time, the final setting time of WSA was extended.

The overall effect of soybean-based biomass ashes on the setting time of cement paste was proven to retard the setting time. Both initial and final setting time were extended in relation to the setting time of OPC. WSSA has a considerably increased initial setting time, which may be caused by the presence of unburnt organic substances-straw remains.

An extended setting time could be an advantage, as it makes cement composites remain workable for a longer period of time, which is especially useful in warmer days.

\subsection{Soundness}

According to the criteria given in EN 196-3 [35] and EN 197-1 [70], the soundness shall not be greater than $10 \mathrm{~mm}$. As all types of biomass ashes showed negligible expansion, up to $1 \mathrm{~mm}$, the criteria are fulfilled. The results are given in Table 12 .

Table 12. Soundness of biomass ashes.

\begin{tabular}{ccl}
\hline & Expansion $(\mathbf{m m})$ & Criterion \\
\hline C & 0 & fulfilled \\
\hline WSA & 0.5 & fulfilled \\
\hline WSSA & 1 & fulfilled \\
\hline SSA & 1 & fulfilled \\
\hline
\end{tabular}

\subsection{Activity Index}

The results of testing activity index are presented in Figure 8.

According to the criteria given in standard EN 450-1 [36], the activity index at 28 days and at 90 days shall not be less than $75 \%$ and $85 \%$, respectively. The WSSA and SSA samples do not meet these requirements, while WSA fulfilled not only the prescribed criteria but it achieved compressive strength higher than that of the reference mortar. At the age of 28 days, the pozzolanic reaction of WSA was not intensified yet and thus the strength increase can be attributed to the filler effect of small particles of WSA.

Other tested ashes, WSSA and SSA, do not meet standards due to a lower amount of reactive silica and, consequently, insufficient pozzolanic activity. 


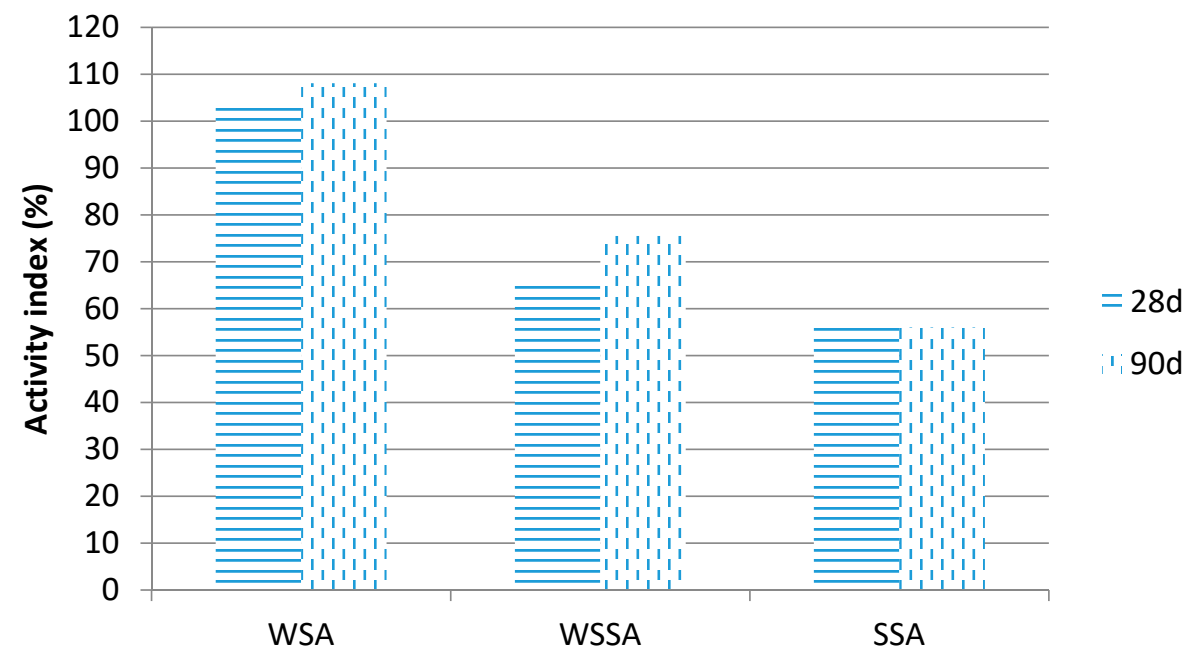

Figure 8. Activity index of biomass ashes.

\subsection{Improving Activity Index with Additional Grinding}

One of the key factors affecting the reactivity of pozzolans is their fineness. In order to improve filler effects of the biomass ashes with insufficient activity index, the ashes were additionally ground (for $12 \mathrm{~h}$ ), achieving thereby Blaine fineness of $15,000.00 \mathrm{~cm}^{2} / \mathrm{g}$. This approach enabled recording the pure effect of fineness on biomass ash reactivity (filler effect). The results are presented in Figures 9 and 10.

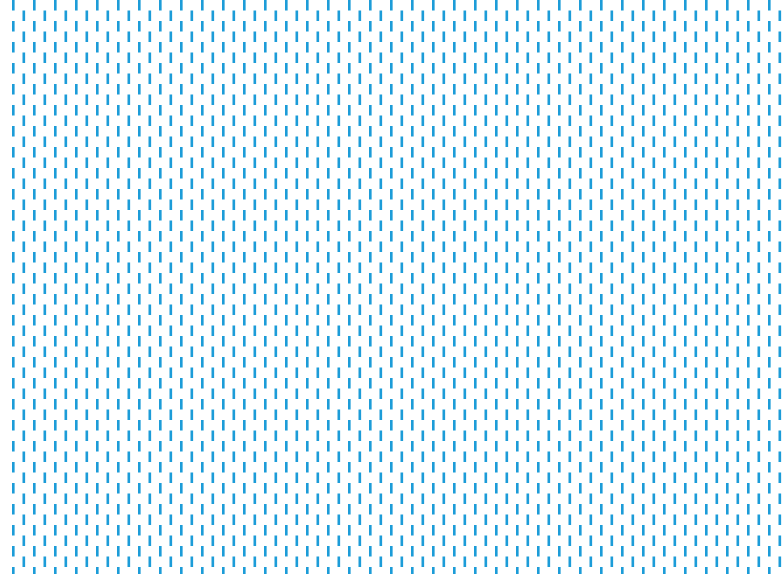

Figure 9. Activity index of additionally ground WSSA (* additionally ground sample).

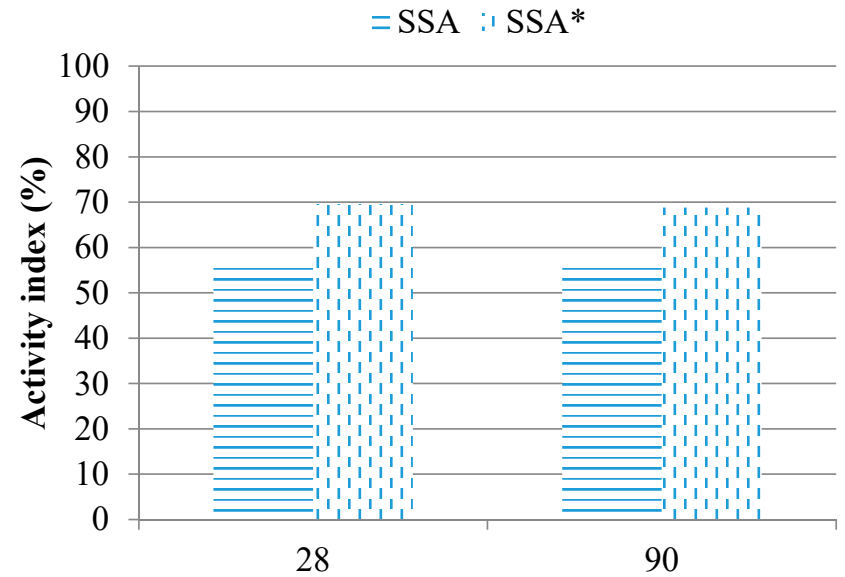

Figure 10. Activity index of additionally ground SSA (* additionally ground sample). 
Additional grinding increased the level of fineness of biomass ashes, which had a positive impact on their activity index.

The activity index of WSSA, after 28 and 90 days, was $91.7 \%$ and $91.8 \%$, respectively, thereby exceeding the required values. At the age of 28 days, the activity index was increased by $27 \%$ (from 65 to $91.7 \%$ ). At the age of 90 days, there was a rise in the activity index by $18 \%$ (from $75.5 \%$ to $91.8 \%$ ).

A growth in SSA activity index of $19 \%$ (from $56.3 \%$ to $69.9 \%$ ) was detected at the age of 28 days, along with an increase of $19 \%$ (from $56 \%$ to $68.8 \%$ ) at the age of 90 days. The achieved values were still below the required criteria, which is a direct consequence of low reactive silica content of this type of biomass ash.

\subsection{Stimulation of Pozzolanic Activity of SSA with Silica Fume}

Two main factors influencing a pozzolanic activity are a reactive silica content and a level of fineness. As the raised level of fineness did not improve the activity index of SSA enough, silica fume, which contains a large amount of reactive silica $(90 \%)$, was used to stimulate its pozzolanic reaction.

The quantity of silica fume was determined stochastically. The replacement level of cement with the mixture of biomass ash and silica fume (in the mass ratio 2:1) was kept at $25 \%$. The aim was to increase the amount of reactive silica of soybean-based biomass ash, which would influence its pozzolanic activity and improve the activity index (Figure 11).

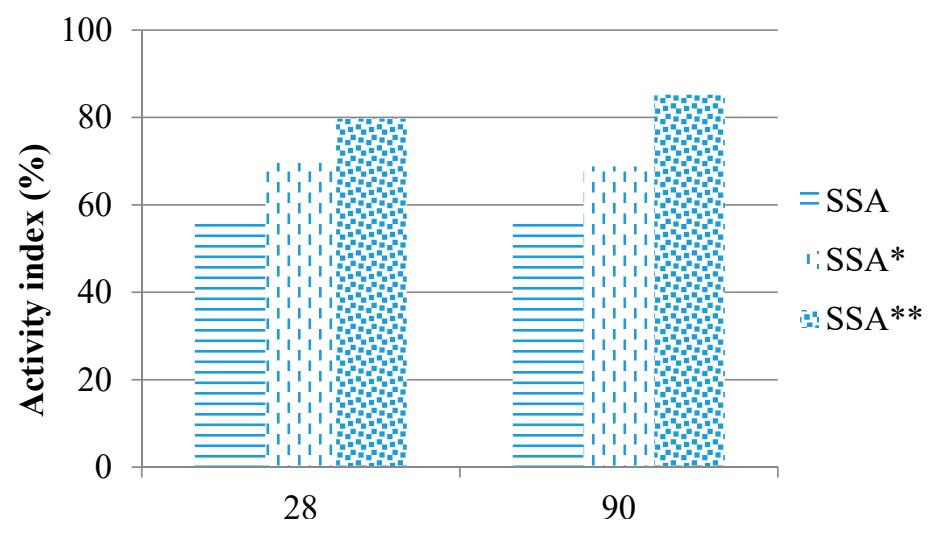

Figure 11. Activity index of additionally ground SSA (* additionally ground sample, ${ }^{* *}$ sample blended with silica fume).

The criteria regarding the activity index of soybean straw ash blended with silica fume were satisfied. The activity index was $80 \%$ and $85.2 \%$ at the age of 28 and 90 days, respectively.

Biomass ash reactivity depends essentially on its fineness, vitreous phase content and chemical composition (reactive silica). Modifying the first parameter via mechanical activation and others via chemical activation are the possible routes to heighten and control their reactivity. The results are in line with Jiménez's research on the reactivity of fly ash [71]. Moreover, the grinding time affects the final pozzolanic performance remarkably, as higher surface area values of the ash lead to more reactive sites for a pozzolanic reaction. Similar trend was observed by Thiedeitz et al. [72].

\section{Conclusions}

The aim of this research was to analyze the ashes originating from harvest residues-WSA, WSSA and SSA — locally available in Vojvodina province. These waste materials are generated at large and small agricultural farms in Vojvodina, derived as by-products within biomass combustion for the purpose of heat energy production. More specifically, the task was to investigate their potential as sustainable building materials by determining their chemical and physical properties and pozzolanic activity. Biomass 
ash reactivity depends heavily on its fineness, amorphous phase content and chemical composition (reactive silica content). Modifying these parameters via mechanical and/or chemical activation could contribute to a greater reactivity of these waste materials. Based on the conducted survey, the following conclusions can be drawn:

- WSA exhibits excellent pozzolanic activity, which can be attributed to a high reactive silica content and a relatively high specific surface of the ash. As the content of soybean-based ash increases, the total reactive silica content decreases, which further reduces the pozzolanic activity of the ash;

- SSA shows the highest hygroscopicity as confirmed by XRF, TGA and FTIR analyses; it also contains the largest amount of carbonates and organic matter relative to WSA and WSSA (confirmed by TGA, FTIR and XRD);

- A wider hump in XRD pattern of WSA and WSSA compared to SSA indicates that they abound in amorphous phase (silicate) which accounts for their higher pozzolanic activity to a certain extent;

- Additional grinding in the laboratory ball mill increases the level of fineness of WSSA, induces its filler effect and improves its activity index. Mechanical activation has only a minor effect on SSA reactivity, hence silica fume can be used to stimulate its pozzolanic activity;

- All types of biomass ashes are characterized with no significant leaching values of heavy metals and can be classified as inert materials, thereby satisfying ecological aspects of SCM utilization.

It can be stated that mechanical activation through grinding procedure and chemical activation by modifying the chemical composition of the ash are efficient at producing pozzolanic materials from biomass wastes. Also, the choice of activation method depends on the chemical composition of biomass ash, i.e., its reactive silica content. The presented research shows that non-traditional waste materials, specifically soy-bean straw ashes characterized by low silica content, can be exploited as potential cement substitutes when some of the proposed adjustment/processing techniques are used. An environmentally friendly route for this type of waste was defined, offering an opportunity for the creation of new sustainable cement-based composites.

Author Contributions: Conceptualization, M.M. and S.Š.; methodology, S.Š., V.B. and T.M.; validation, S.Š.; investigation, M.M. and S.Š.; resources, V.R., M.M.; writing—original draft preparation, S.Š.; writing—review and editing, S.Š., V.B., M.M. and T.M.; visualization, S.Š. and V.B.; supervision, M.M. and V.R.; project administration, S.S.; funding acquisition, M.M. All authors have read and agreed to the published version of the manuscript.

Funding: Department of civil engineering and geodesy, Faculty of technical sciences, Novi Sad, Serbia.

Institutional Review Board Statement: Not applicable.

Informed Consent Statement: Not applicable.

Data Availability Statement: Data sharing not applicable.

Acknowledgments: The paper presents the part of research realized within the project "Multidisciplinary theoretical and experimental research in education and science in the fields of civil engineering, risk management and fire safety and geodesy" conducted by the Department of Civil Engineering and Geodesy, Faculty of Technical Sciences, University of Novi Sad.

Conflicts of Interest: The authors declare no conflict of interest.

\section{References}

1. Thomas, B.S. Green concrete partially comprised of rice husk ash as a supplementary cementitious material—A comprehensive review. Renew. Sustain. Energy Rev. 2018, 82, 3913-3923. [CrossRef]

2. Park, K.B.; Kwon, S.J.; Wang, X.Y. Analysis of the effects of rice husk ash on the hydration of cementitious materials. Constr. Build. Mater. 2016, 105, 196-205. [CrossRef] 
3. Memon, S.A.; Khan, M.K. Ash blended cement composites: Eco-friendly and sustainable option for utilization of corncob ash. J. Clean. Prod. 2018, 175, 442-455. [CrossRef]

4. Qudoos, A.; Kim, H.G.; Rehman, A.; Ryou, J.S. Effect of mechanical processing on the pozzolanic efficiency and the microstructure development of wheat straw ash blended cement composites. Constr. Build. Mater. 2018, 193, 481-490. [CrossRef]

5. Chindaprasirt, P.; Rukzon, S.; Sirivivatnanon, V. Resistance to chloride penetration of blended Portland cement mortar containing palm oil fuel ash, rice husk ash and fly ash. Constr. Build. Mater. 2015, 22, 932-938. [CrossRef]

6. Moraes, J.C.B.; Akasaki, J.L.; Melges, J.L.P.; Monzó, J.; Borrachero, M.V.; Soriano, L.; Payá, J.; Tashima, M.M. Assessment of sugar cane straw ash (SCSA) as pozzolanic material in blended Portland cement: Microstructural characterization of pastes and mechanical strength of mortars. Constr. Build. Mater. 2015, 94, 670-677. [CrossRef]

7. Aksoğan, O.; Binici, H.; Ortlek, E. Durability of concrete made by partial replacement of fine aggregate by colemanite and barite and cement by ashes of corn stalk, wheat straw and sunflower stalk ashes. Constr. Build. Mater. 2016, 106, 253-263. [CrossRef]

8. Cociñaa, E.V.; Morales, E.V.; Santos, S.F.; Savastano, H., Jr.; Frías, M. Pozzolanic behavior of bamboo leaf ash: Characterization and determination of the kinetic parameters. Cem. Concr. Compos. 2011, 33, 68-73. [CrossRef]

9. Alaneme, K.K.; Eze, H.I.; Bodunrin, M.O. Corrosion behaviour of groundnut shell ash and silicon carbide hybrid reinforced Al-Mg-Si alloy matrix composites in 3.5\% NaCl and 0.3 $\mathrm{M} \mathrm{H}_{2} \mathrm{SO}_{4}$ solutions. Leonardo Electron. J. Pract. Technol. 2015, 26, 141-158.

10. Raheem, A.A.; Ige, A.I. Chemical composition and physicomechanical characteristics of sawdust ashblended cement. J. Build. Eng. 2019, 21, 404-408. [CrossRef]

11. Li, G.; Xu, X.; Chen, E.; Fan, J.; Xiong, G. Properties of cement-based bricks with oyster-shells ash. J. Clean. Prod. 2015, 91, 279-287. [CrossRef]

12. Wigley, F.; Williamson, J.; Malmgren, A.; Riley, G. Ash deposition at higher levels of coal replacement by biomass. Fuel Process. Technol. 2007, 88, 1148-1154. [CrossRef]

13. Risnes, H.; Fjellerup, J.; Henriksen, U.; Moilanen, A.; Norby, P.; Papadakis, K.; Posselt, D.; Sørensen, L.H. Calcium addition in straw gasification. Fuel 2003, 82, 641-651. [CrossRef]

14. Demirbas, A. Combustion characteristics of different biomass fuels. Prog. Energy Combust. Sci. 2004, 30, 219-230. [CrossRef]

15. Opeyemi, J.; Kolapo, O.O.; Ayobami, A.B.; Ignatius, O.O.; Ayodeji, O.O.; Lekan, M.A.; Chidiogo, J.E. Data on the pozzolanic activity in coconut shell ash (CSA) for use in sustainable construction. Data Brief 2018, 18, 1142-1145.

16. Masiá, T.A.A.; Buhre, B.J.P.; Gupta, R.P.; Wall, T.F. Characterising ash of biomass and waste. Fuel Process. Technol. 2007, 88, 1071-1081. [CrossRef]

17. Campos Teixeira, A.H.; Soares Junior, P.R.R.; Silva, T.H.; Barreto, R.R.; Bezerra, A.C.D.S. Low-Carbon Concrete Based on Binary Biomass Ash-Silica Fume Binder to Produce Eco-Friendly Paving Blocks. Materials 2020, 13, 1534. [CrossRef]

18. Xu, W.; Lo, T.Y.; Memon, S.A. Microstructure and reactivity of rich husk ash. Constr. Build. Mater. 2012, 29, 541-547. [CrossRef]

19. Josephin, A.; Dhanalakshmi, J.; Ambedkar, B. Experimental investigation on rice husk ash as cement replacement on concrete production. Constr. Build. Mater. 2016, 127, 353-362.

20. Fapohunda, C.; Akinbile, B.; Shittu, A. Structure and properties of mortar and concrete with rice husk ash as partial replacement of ordinary Portland cement-A review. Int. J. Sustain. Built Environ. 2017, 6, 675-692. [CrossRef]

21. Madandoust, R.; Mohammad, R.M.; Moghadamb, H.A.; Mousavi, S.Y. Mechanical properties and durability assessment of rice husk ash concrete. Biosyst. Eng. 2011, 110, 144-152. [CrossRef]

22. Jankovský, O.; Pavlíková, M.; Sedmidubský, D.; Bouša, D.; Lojka, M.; Pokorný, J.; Záleská, M.; Pavlík, Z. Study on pozzolana activity of wheat straw ash as potential admixture for blended cements. Ceram.-Silik. 2017, 61, 327-339. [CrossRef]

23. Khushnood, R.A.; Rizwan, S.A.; Memon, S.A.; Tulliani, J.; Ferro, G.A. Experimental investigation on use of wheat straw ash and bentonite in self-compacting cementitious system. Adv. Mater. Sci. Eng. 2014, 2014, 1-11. [CrossRef]

24. Goyal, A.; Kunio, H.; Ogata, H.; Garg, M.; Anwar, A.M.; Ashraf, M.; Mandula, M. Synergic effect of wheat straw ash and rice-husk ash on strength properties of mortar. J. Appl. Sci. 2007, 7, 3256-3261. [CrossRef]

25. Biricik, H.; Akoz, F.; Turker, F.; Berktay, I. Resistance to magnesium sulfate and sodium sulfate attack of mortars containing wheat straw ash. Cem. Concr. Res. 2000, 30, 1189-1197. [CrossRef]

26. The Food and Agriculture Organization (FAO). World Food Situation. Available online: http://www.fao.org/worldfoodsituation/ csdb/en/ (accessed on 17 February 2019).

27. Index Mundi. Agriculture. World Production. Available online: https://www.indexmundi.com/agriculture/?commodity= wheat\&graph=production (accessed on 17 February 2019).

28. Index Mundi. Agriculture. World Production. Available online: https://www.indexmundi.com/agriculture/?commodity= soybean-oilseed\&graph=production (accessed on 17 February 2019).

29. Šupić, S.; Malešev, M.; Radonjanin, V.; Radeka, M.; Laban, M. Application of Biomass Ashes as Supplementary Cementitious Materials in the Cement Mortar Production. World Academy of Science, Engineering and Technology. Int. J. Struct. Constr. Eng. 2018, 12, 703-709.

30. Radonjanin, V.; Malešev, M.; Šupić, S.; Radeka, M. Influence of filler effect and pozzolanic reaction of biomass ashes on mechanical properties of cement mortars. In Interdisciplinary Approaches for Cement-Based Materials and Structural Concrete, Synergizing Expertise and Bridging Scales of Space and Time; RILEM Publications S.A.R.L.: Madeira, Portugal, 2018; Volume 1, pp. 511-516.

31. Method of Testing Cement, Part 2. Chemical Analysis of Cement; EN 196-2; European Committee for Standardization (CEN): Brussels, Belgium, 2015. 
32. Cement-Test Methods, Part 2. Chemical Analysis by X-ray Fluorescence; ISO 29581-2; BSI: Geneva, Switzerland, 2010.

33. Characterisation of Waste-Leaching_Compliance Test for Leaching of Granular Waste Materials and Sludges-Part 2: One Stage Batch Test at a Liquid to Solid Ratio of $10 \mathrm{l} / \mathrm{kg}$ for Materials with Particle Size below $4 \mathrm{~mm}$ (without or with Size Reduction); SRPS EN 12457-2:2008; Institute for Standarddization of Serbia: Beograd, Serbia, 2008.

34. Methods of Testing Cement, Determination of Fineness; EN 196-6; European Committee for Standardization (CEN): Brussels, Belgium, 2011.

35. Methods of Testing Cement, Part 3. Determination of Setting Times and Soundness; EN 196-3; European Committee for Standardization (CEN): Brussels, Belgium, 2010.

36. Fly Ash for Concrete, Part 1. Definition, Specifications and Conformity Criteria; EN 450-1; European Committee for Standardization (CEN): Brussels, Belgium, 2014.

37. Non-Metallic Mineral Raws, Pozzolanic Materials, Constituents for Cement Production Classification, Technical Conditions and Test Methods; SRPS B.C1.018; Institute for Standarddization of Serbia: Beograd, Serbia, 2015.

38. Methods of Testing Cement, Part 1. Determination of Strength; EN 196-1; European Committee for Standardization (CEN): Brussels, Belgium, 2018.

39. Mahmoud, H. Effect of Alkalis and Sulfates on Portland Cement Systems. Graduate Theses and Dissertations, University of South Florida. 2006. Available online: https:/ / scholarcommons.usf.edu/etd/2542/ (accessed on 17 February 2019).

40. Mtarfi, N.H.; Rais, Z.; Taleb, M. Effect of clinker free lime and cement fineness on the cement physicochemical properties. J. Mater. Environ. Sci. 2017, 8, 2541-2548.

41. Noirfontaine, M.N.; Tusseau-Nenez, S.; Signes-Frehel, M.; Gasecki, G.; Girod-Labianca, C. Effect of phosphorus on tricalcium silicate T1: From synthesis to structural characterization. J. Am. Ceram. Soc. Wiley 2009, 92, 2337-2344. [CrossRef]

42. Michael, P. Compost quality definition-legislation and standards. Work. Group Compost. Consult. Dev. Tech. Off. Agric. 2004. Annex 2.

43. Council of the European Union. Council Directive 1999/31/EC of 26 April 1999 on the landfill of waste. EUR-Lex 1999, 182, 1-19.

44. Evic, N.; Brunner, T.; Obernberger, I. Prediction of biomass ash melting behaviour-correlation between the data obtained from thermodynamic equilibrium calculations and simultaneous thermal analysis (STA). In Proceedings of the 20th European Biomass Conference and Exhibition, Milan, Italy, 18-22 June 2012; pp. 807-813.

45. Esteves, T.C.; Rajamma, R.; Soares, D.; Silva, A.S.; Ferreira, V.M.; Labrincha, J.A. Use of biomass fly ash for mitigation of alkali-silica reaction of cement mortars. Constr. Build. Mater. 2012, 26, 687-693. [CrossRef]

46. Umamaheswaran, K.; Batra, V.D. Physico-chemical characterisation of Indian biomass ashes. Fuel 2008, 87, 628-638. [CrossRef]

47. Febrero, L.; Granada, E.; Pérez, C.; Patiño, D.; Arce, E. Characterisation and comparison of biomass ashes with different thermal histories using TG-DSC. J. Therm. Anal. Calorim. 2014. [CrossRef]

48. Arvelakis, S.; Arendt, J.P.; Dam-Johansen, K. Simultaneous Thermal Analysis (STA) on Ash from High-Alkali Biomass. Energy Fuels 2004, 18, 1066-1076. [CrossRef]

49. Mäkelä, M.; Paananen, T.; Kokkonen, T.; Makkonen, H.; Heino, J.; Dahl, O. Preliminary Evaluation of Fly Ash and Lime for Use as Supplementary Cementing Materials in Cold-Agglomerated Blast Furnace Briquetting. ISIJ Int. 2011, 51, 776-781. [CrossRef]

50. Arvelakis, S.; Gehrmann, H.; Beckmann, M.; Koukios, E.G. Studying the ash behaviour of agricultural residues using Thermal Analysis. J. Therm. Anal. Calorim. 2003, 72, 1019-1030. [CrossRef]

51. Bonet-Martínez, E.; García-Cobo, P.; Pérez-Villarejo, L.; Castro, E.; Eliche-Quesada, D. Effect of olive-pine bottom ash on properties of geopolymers based on metakaolin. Materials 2020, 13, 901. [CrossRef]

52. Jeyageetha, C.J.; Kumar, S.P. Study of SEM/EDXS and FTIR for Fly Ash to Determine the Chemical Changes of Ash in Marine Environment. Int. J. Sci. Res. 2013, 5, 1688-1692.

53. Pérez-Villarejo, L.; Bonet-Martínez, E.; Eliche-Quesada, D.; Sánchez-Soto, P.J.; Rincón-López, J.M.; Castro-Galiano, E. Biomass fly ash and aluminium industry slags-based geopolymers. Mater. Lett. 2018, 229, 6-12.

54. Kalembkiewicz, J.; Galas, D.; Sitarz-Palczak, E. The Physicochemical Properties and Composition of Biomass Ash and Evaluating Directions of its Applications. Pol. J. Environ. Stud. 2018, 27, 2593-2603. [CrossRef]

55. Verşan, K.M.; Ozgur, E. Characterization of lignocellulose biomass and model compounds by thermogravimetry. Energy Sources Part A Recovery Util. Environ. Eff. 2007, 39, 134-139. [CrossRef]

56. Liu, Y.; Zeng, F.; Sun, B.; Jia, P.; Graham, I.T. Structural Characterizations of Aluminosilicates in Two Types of Fly Ash Samples from Shanxi Province, North China. Minerals 2019, 9, 358. [CrossRef]

57. Criado, M.; Fernández-Jiménez, A.; Palomo, A. Alkali activation of fly ash: Effect of the $\mathrm{SiO}_{2} / \mathrm{Na}_{2} \mathrm{O}$ ratio Part I: FTIR study. Microporous Mesoporous Mater. 2007, 106, 180-191. [CrossRef]

58. Vempati, R.K.; Rao, A.; Hess, T.R.; Cocke, D.L.; Lauer, H.V., Jr. Fractionation and characterization of Texas lignite class F fly ash by XRD, TGA, FTIR and SFM. Cem. Concr. Res. 1994, 24, 1153-1164. [CrossRef]

59. Soltan, H.H.; Abdel-Gawwad, H.A.; Vasquez-García, S.R.; Israde-Alcantara, I.; Flores-Ramirez, N.; Rico, J.L.; Mohammed, M.S. Cleaner production of one-part white geopolymer cement using pretreated wood biomass ash and diatomite. J. Clean. Prod. 2019, 209, $1420 \mathrm{e} 1428$.

60. Çetintaş, R.; Soyer-Uzun, S. Relations between structural characteristics and compressive strength in volcanic ash based one-part geopolymer systems. J. Build. Eng. 2018, 20, 130-136. [CrossRef] 
61. Assad, M.M.; Hussain, K.A.; Hassanb, M.; Liaquatb, R. Biomass ash characterization, fusion analysis and its application in catalytic decomposition of methane. Fuel 2021, 285, 119107. [CrossRef]

62. Masto, R.E.; Pandit, A.; Kumar, S.; Datta, S.; Mukhopadhyay, S.; Selvi, V.A.; Dutta, P.; Sarkar, P. Comparative evaluation of aquatic biomass feedstocks for energy application and potential for extraction of plant nutrients from their ash. Biomass Bioenergy 2020, 142, 105783. [CrossRef]

63. Jose, A.; Nivitha, M.R.; Murali, K.J.; Robinson, R.G. Characterization of cement stabilized pond ash using FTIR spectroscopy. Constr. Build. Mater. 2020, 263, 120136. [CrossRef]

64. Cretescu, I.; Harja, M.; Teodosiu, C.; Isopescu, D.N.; Chok, M.F.; Sluser, B.M.; Salleh, M.A.M. Synthesis and characterisation of a binder cement replacement basedon alkali activation of fly ash waste. Process. Saf. Environ. Prot. 2018, 119, 23-35. [CrossRef]

65. Zhang, W.; Liu, C. The effect of diesel emulsification using sodium petroleum sulfonate on carbon flotation from fly ash. Waste Manag. 2019, 98, 144-150. [CrossRef] [PubMed]

66. Hernandez-Martínez, D.; Leyva-Verduzco, A.A.; Rodríguez-Felix, F.; Acosta-Elías, M.; Wong-Corral, F.J. Obtaining and characterization of silicon (Si) from wheat husk ash for its possible application in solar cells. J. Clean. Prod. 2020, $271,122698$. [CrossRef]

67. Osman, N.S.; Sapawe, N. Preparation of amorphous oil palm frond ash (OPFA) via acid leaching treatment as precursor for silica synthesis. Mater. Today Proc. 2020, 31, 253-256. [CrossRef]

68. Cheng, S.Y.; Liu, Y.Z.; Qi, G.S. Experimental study of $\mathrm{CO}_{2}$ capture enhanced by coal fly ash-synthesized NH2-MCM-41 coupled with high gravity technology. Chem. Eng. J. 2020, 400, 125946. [CrossRef]

69. Ikubanni, P.P.; Oki, M.; Adeleke, A.A.; Adediran, A.A.; Adesina, O.S. Influence of temperature on the chemical compositions and microstructural changes of ash formed from palm kernel shell. Results Eng. 2020, 8, 100173. [CrossRef]

70. Cement Composition, Specifications and Conformity Criteria for Common Cements; EN 197-1:2011; European Committee for Standardization (CEN): Brussels, Belgium, 2011.

71. Fernández-Jiménez, A.; Garcia-Lodeiro, I.; Maltseva, O.; Palomo, A. Mechanical-Chemical Activation of Coal Fly Ashes: An Effective Way for Recycling and Make Cementitious. Materials. Front. Mater. 2019. [CrossRef]

72. Thiedeitz, M.; Schmidt, W.; Härder, M.; Kränkel, T. Performance of Rice Husk Ash as Supplementary Cementitious Material after Production in the Field and in the Lab. Materials 2020, 13, 4319. [CrossRef] 